\title{
Modifying tumor associated macrophage function through cannabinoid receptor 2
}

\author{
Taxiarhia Arabatzis", Taylor Littlefield, Jordan Watson, Jason Thole, Elizabeth McAndrew, Katherine E Hanlon \\ From 30th Annual Meeting and Associated Programs of the Society for Immunotherapy of Cancer (SITC 2015) \\ National Harbor, MD, USA. 4-8 November 2015
}

In human breast cancers, tumor infiltration by tumor associated macrophages (TAMs) correlates with multiple markers of poor prognosis: higher tumor macrophage counts are associated with higher tumor grade, higher tumor vascular density, and reduced overall survival [1]. TAMs secrete biologically active molecules that promote tumor growth and metastasis[1]. Additionally, unique subpopulations of TAMs contribute to the immunosuppressive microenvironment that significantly enhances tumor genesis by limiting vital anti-tumor immune responses [2], however the mechanisms that regulate TAM development and their actions within the tumor microenvironment remain poorly understood. Pre-clinical studies demonstrate that macrophage ablation retards tumor progression[3], suggesting that TAMs may be a viable target for eliciting an anti-tumor response. We have therefore begun to analyze the effects of novel cannabinoid agonists on TAMs in a murine model of breast cancer. Macrophage expression of cannabinoid receptor $2\left(\mathrm{CB}_{2}\right)$ is induced by inflammatory stimuli and regulates multiple functions including chemotaxis and antigen presentation[4]. Recent findings in our lab and by others indicate that $\mathrm{CB}_{2}$ agonists significantly reduce tumor burden and metastasis in several models. Although the in vivo anti-tumor efficacy of cannabinoids is mimicked in continuously cultured cancer cells in vitro, cannabinoid potency for direct elicitation of apoptosis in cancer cells is far lower, indicating that other mechanisms (perhaps other cell types within the tumor) are involved in vivo. We have recently obtained evidence that: 1) $\mathrm{CB}_{2}$ agonists mediate inhibition of primary tumor growth and metastasis in vivo, 2) significant infiltration of TAMs occurs within the developing tumor in this murine model, 3) administration of a $\mathrm{CB}_{2}$ agonist increases populations of pro-inflammatory M1

University of New England, Biddeford, ME, USA macrophages (MHC Class II-high, iNOS high) in both the primary tumor and in the spleen of tumor bearing mice, and 4) a concurrent increase in the proportion of $\mathrm{CD} 8+$ cytotoxic $\mathrm{T}$ lymphocytes is also observed within the primary tumor upon $\mathrm{CB}_{2}$ agonist treatment.

Published: 4 November 2015

\section{References}

1. Medrek C, et al: The presence of tumor associated macrophages in tumor stroma as a prognostic marker for breast cancer patients. BMC Cancer 2012, 12:306.

2. Solinas $G$, et al: Tumor-associated macrophages (TAM) as major players of the cancer-related inflammation. J Leukoc Biol 2009, 86(5):1065-73.

3. Lin EY, et al: Colony-stimulating factor 1 promotes progression of mammary tumors to malignancy. J Exp Med 2001, 193(6):727-40.

4. Klein TW, et al: The cannabinoid system and immune modulation. J Leukoc Biol 2003, 74(4):486-96.

\section{doi:10.1186/2051-1426-3-S2-P291}

Cite this article as: Arabatzis et al:: Modifying tumor associated macrophage function through cannabinoid receptor 2. Journal for ImmunoTherapy of Cancer 2015 3(Suppl 2):P291.
Submit your next manuscript to BioMed Central and take full advantage of:

- Convenient online submission

- Thorough peer review

- No space constraints or color figure charges

- Immediate publication on acceptance

- Inclusion in PubMed, CAS, Scopus and Google Scholar

- Research which is freely available for redistribution
() Biomed Central 